\section{In Vitro and in Vivo Antineoplastic Activity of Barbatic Acid}

Mônica Cristina Barroso Martins ${ }^{1}$,

Tamiris Alves Rocha', Thiago David Santos Silva', Marinaldo Pacífico CavalcantiNeto ${ }^{2}$,

Noemia Pereira da Silva Santos ${ }^{2}$, Teresinha Gonçalves da Silva ${ }^{3}$, Francisco Carlos Amanajás Aguiar-Junior ${ }^{2}$,

Emerson Peter da Silva Falcão², Eugênia C Pereira ${ }^{4}$,

Nicácio Henrique da Silva ${ }^{1}$ . Several of them are potent anticancer agent and some with ic or none toxicity. The aim of this study was to perform in vitro and in vivo assessments of the antineoplastic activity of organic extract and barbatic acid (BAR) isolated from the lichen Cladia aggregata (Sw.) Nyl.

Methods: In vitro assays were performed with both extract and BAR against HEp-2 (Adenocarcinoma of the Larynx), NCl-H292 (Squamous Cell Lung Carcinoma) and KB (Nasopharyngeal Squamous Cell Carcinoma) cells. The tests were carried out on the Sarcoma-180 BAR, tumor and organs were analyzed by histopathological assays after 7 days of chemotherapy.

Results: Cytotoxic tests with BAR revealed $50 \%$ inhibitory concentration $\left(\mathrm{IC}_{50}\right)$ of $19.06 \mu \mathrm{g} \mathrm{mL}^{-1}$ for $\mathrm{NCl}-\mathrm{H} 292$ and $12.0 \mathrm{~g} \mathrm{~mL}^{-1}$ for KB and $6.25 \mathrm{mg} \mathrm{mL}^{-1}$ for HEp-2 cells. Tests with Sarcoma-180 demonstrated $46.3 \%$ inhibitory activity against the tumor by BAR. This substance showed no significant effect on the expression of argyrophilic nucleolar organizer regions proteins (AgNORs). The histopathology study of neoplastic tissue, demonstrated that cell proliferation was not affected by the antineoplastic action of the compound tested.

Conclusions: The results indicate that both barbatic acid and ether extract exhibits significant antineoplastic activity and low toxicity rate.

\section{Background}

The increase in the incidence of malignant tumors worldwide has stimulated the search for new drugs and therapies that may control the spread of cancer. The available pharmaceutical arsenal is composed of substances of natural or synthetic origin. However, the particularities of each tumor type and possible resistance to chemotherapeutic drugs
1 Departament of Biochemistry, Universidade Federal de Pernambuco, UFPE, Recife/Pernambuco, Brazil.

2 Academic Centre of Vitória, Universidade Federal de Pernambuco, UFPE, Vitória de Santo Antão, Pernambuco, Brazil.

3 Departament of Antibiotics, Universidade Federal de Pernambuco, UFPE, Recife/Pernambuco, Brazil.

4 Departament of Geographic Sciences, Universidade Federal de Pernambuco, UFPE, Recife/Pernambuco, Brazil.

Contact information:

Eugênia C. Pereira.

Address: Avenida Prof. Moraes Rego, 1235. Cidade Universitária. Recife, $P E$, Brazil. CEP: 50.740670-901.

Tel: 5581999009777.

झ verticillaris@gmail.com

Keywords

Antitumor; Citotoxity activity;

Depside; Lichen; Lichen

substance; Natural Compound. 
constitute obstacles that underscore the need for new drugs with antineoplastic activity [1].

Lichens are biological structures formed by a combination of a mycobiont (fungus) and one or more photobionts (algae and or cyanobacteria). Specialists agree that the combination ranges from parasitism to a strict mutualism [2]. However, this combination is delicately balanced and any alteration in the growth and/or death rates of the components may lead to the death of the lichen. Lichen symbiosis is a successful evolutionary strategy that can result in a rich diversity of fungal species that produce exclusive substances of great biological potential from the depside, depsidone and dibenzofuran class (usnic acids), among others [3].

Lichen compounds commonly have two aromatic rings, the ideal orientation of which is approximately $125^{\circ}$. Carboxyl and hydroxyl are fundamental to biological activity in these substances [4]. Pharmacological use of lichen extracts includes antifungal [5], antibacterial [6, 7] and antitumor [8, 9] activity, as well as the prevention of cancer cells.

With regard to antineoplastic activity, there are promising reports associating compounds that are metabolically related to barbatic acid with the in vitro inhibition of cancer development. LIMA et al. [10] describe the inhibitory action of usnic acid (80\% against Sarcoma-180) extracted from Cladonia substellata. SANTOS et al. [11] describe similar results with this in a nanoencapsulated form. Methanol extracts of Umbilicaria esculenta and Usnea longissima significantly reduce melanin formation in human melanomas [12]. Sphaerophorin (depside) and pannarin (depsidone) have the same effect, inducing cell death by apoptosis [13]. The inhibition of tubulin polymerization has been described for substances from the lichen Stereocaulon sasakii, particularly lobaric acid [4]. Nevertheless, recent studies indicate that not all compounds have the same active site. For example, usnic acid inhibits the proliferation of breast tumors at a concentration of $29 \mu \mathrm{M}$, but does not alter the formation and/or stability of microtubules, which suggests that there is no association between microtubules and the action mechanism of this compound [14].

Due the potential activity of lichen compounds, the study of their extracts and purified substances constitutes a contribution to the knowledge of the natural products for treatment and cure of diseases. In addition, new compounds with low or no degree of toxicity are desirable, due to side and adverse effects of drugs used in chemotherapy. This way, the aim of the present study was to perform assays in vitro and in vivo the antineoplastic activity of barbatic acid and ethereal extract obtained from the lichen Cladia aggregata, in order to contribute to the search for new anticancer drugs with antitumor activity.

\section{Methods}

\section{Collection and storage of lichen}

Cladia aggregata (Sw.) Nyl. samples (200 g) were previously identified by Dr. E.C. Pereira through morphological and chemical analysis. The material was collected Bonito municipality, Brazil. The lichen was stored in paper bags and kept at room temperature $\left(28 \pm 3^{\circ} \mathrm{C}\right)$ until tests be performed. A specimen was deposited in the Herbarium UFP - Geraldo Mariz, of the Botany Department, Universidade Federal de Pernambuco (Brazil) voucher $n^{\circ} 36431$.

\section{Obtainment of extracts and isolation, purification and chemical characterization of barbatic acid (BAR)}

Organic lichen extracts were obtained using Soxhlet extraction $\left(30^{\circ} \mathrm{C}\right)$ using diethyl ether. BAR isolation and purification from ether extract, as well as chemical characterization/spectroscopic assays determined by HPLC, TLC, 1H, 13C NMR and UV spectra were based on the data described by Martins et al. [6]. 


\section{Cytotoxic assays}

Cytotoxic activity and cell viability cytotoxicity tests were performed with the HEp-2 (Adenocarcinoma of the Larynx), NCl-H292 (Squamous Cell Lung Carcinoma) and KB (Nasopharyngeal Squamous Cell Carcinoma) cell lines provided by the Cell Culture Laboratory, Department of Antibiotics, Universidade Federal de Pernambuco (Brazil). Cells were kept in Minimum Essential Medium, Dulbecco's Modified Eagle's Medium (SIGMA), supplemented with $10 \%$ Fetal Bovine Serum (GIBCO), 1\% antibiotic solution (1000 U $\mathrm{mL}^{-1}$ of penicillin $+250 \mathrm{mg} \mathrm{mL}^{-1}$ of streptomycin) and $200 \mathrm{mM}$ of $1 \%$ L-glutamine [15]. The cell suspensions $\left(10^{5}\right.$ cells $\left.\mathrm{mL}^{-1}\right)$ were distributed in 96 culture plates $(220 \mu \mathrm{L} /$ plate). The plates were incubated at $37^{\circ} \mathrm{C}$ (Sedas, Milan-Italy) with a humid atmosphere supplied with $5 \% \mathrm{CO}_{2}$. After 24 h of incubation, $22 \mu \mathrm{L} /$ plate of barbatic acid and/ or ether extract were added, diluted in DMSO at final concentrations of $20,10,5$ and $2.5 \mu \mathrm{g} \mathrm{mL}^{-1}$ for BAR and 6.5, 12, 25 and $50 \mathrm{mg} \mathrm{mL}^{-1}$ for ether extract. DMSO was used as the control. After $72 \mathrm{~h}$ of treatment, the cytotoxic effects of the samples were assessed using the MTT colorimetric method 3- (4.5-dimethylthiazol-2.5-diphenyltetrazolium) (MTT). Cell viability was determined using $0.4 \%$ Trypan Blue vital dye (Merck). The results were assessed in terms of cell inhibition in comparison to the control group, with the determination of the percentage of living and dead cells [16].

\section{In vivo assays}

\section{Determination $\left(\mathrm{LD}_{50}\right)$ and antitumor activity}

The antitumor activity assays were preceded by tests for the determination of the toxicity of the pyrimidine derivatives, following the methodology proposed by Karber and Berhrens [17] and modified by Berlion [18]. Male albino Swiss mice were used in the experiments, divided into two groups of ten animals. The administration technique was intraperitoneal injection.
The assays consisted of preliminary phase and definitive phases. In the preliminary phase, the animals were divided into three groups and received the test drug (BAR) in a single dose at increasing concentrations, following a geometric progression with a common ratio of 2.0. The aim was to determine the highest non-lethal dose $\left(D_{1}\right)$ and the lowest 100\% lethal dose $\left(D_{2}\right)$. Then the animals received doses of the drug ranging between $D_{1}$ and $D_{2}$, following a geometric progression with a common ratio of 1.5 . In the sequence, the animals were observed for $4 \mathrm{~h}$ (with notes recorded every 10 minutes) and monitored for periods of 24,48 and $72 \mathrm{~h}$. The final results were determined using the following formula: $L D$ $50 \%=\mathrm{Df}-\Sigma(\mathrm{a} . \mathrm{b}) / \mathrm{n} . \mathbf{D f}=$ lowest $100 \%$ lethal dose; $\mathrm{a}=$ difference between two consecutive doses; $\mathbf{b}=$ mean number of dead animals between two consecutive doses; $\mathbf{n}=$ number of mice per batch; LD = lethal dose.

\section{Antitumor activity}

Female albino Swiss mice (Mus musculus) with a mean weight of $48.25 \mathrm{~g}$ provided with chow (Labina ${ }^{\circledR}$, Purina Brazil Ltd.) and water ad libitum. The mice were divided into two groups $(n=5)$ and subsequently inoculated in the right axillary region with a tumor cell suspension $(0.2 \mathrm{~mL}$ at a concentration of $5 \times 10^{6}$ cells $\mathrm{mL}^{-1}$ ) developing a solid tumor (Sarcoma-180) provided by the Department of Antibiotics, Universidade Federal de Pernambuco (Brazil). The control group received doses of saline solution $0.9 \%$ and Tween 80 at $0.05 \%(\mathrm{v} / \mathrm{V})$ corresponding negative control $\left(\mathrm{C}^{-}\right)$and 5 -Fluorouracil (5-Flor) as positive control $\left(\mathrm{C}^{+}\right)\left(3.5 \mathrm{~mL} \mathrm{~kg}{ }^{-1}\right.$ of body weight) through intraperitoneal injection. The experimental group was treated with doses of $10 \% \mathrm{LD}_{50}$ (75.69 $\mathrm{mg} \mathrm{kg}^{-1}$ ), corresponding to $7.60 \mathrm{mg} \mathrm{kg}^{-1}$ of BAR, every $24 \mathrm{~h}$ for seven days. At the end of the experiment, the mice were sacrificed through cervical dislocation and the tumors were surgically removed and weighed. The tissues and organs were analyzed to determine microscopic changes induced by 
the treatment. The tumor inhibition was determined from the average weight of animals treated groups compared to the untreated group: IT\% $=$ CT/C $x$ $100 \%$, where $C$ is the average weight of the animals from the negative control group $\left(C^{-}\right)$and $T$ is the average weight of the animals in the positive control $\left(\mathrm{C}^{+}=\mathrm{BAR}\right.$ or 5 -Flor). To calculate the average weight of the tumors of the control group was waived those whose weights corresponded to 0.39 g or less, called "no-takes". The entire experimental protocol received prior approval from the Research Ethics Committee of the Universidade Federal de Pernambuco (Brazil) n²3076.016437/2013-18.

\section{Histopathological analysis and argyrophilic nucleolar organizer regions (AgNOR) proteins staining procedure}

Fragments of the tumor, kidneys, liver and spleen were washed with physiological serum and subsequently maintained in a fixative solution of $10 \%$ buffered formaldehyde for $24 \mathrm{~h}$. The resulting biological material was dehydrated, clarified and embedded in paraffin. Semi-serial cuts with a thickness of $5 \mu \mathrm{m}$ were performed. The cuts were stained using the hematoxylin and eosin technique for subsequent histopathological analysis under an optical microscope microscope Nikon E-200.

The technique recommended by Ploton at al. [19] was used to quantify the AgNORs, whereby histological cuts were incubated in a darkroom for 30 minutes at $37^{\circ} \mathrm{C}$ in a colloidal silver solution containing one part gelatin (2\%) in formic acid (1\%) and two parts silver nitrate (50\%) aqueous solution. The slides were dehydrated, clarified and mounted with DPX. Histological images were captured with a digital camera (Moticam 2300) coupled to an optical microscope (Nikon E-200) at a final magnification of $400 \mathrm{X}$. The quantification was performed using the ImageJ 1.44 program (National Institute of Health, Bethesda, MD, USA). AgNORs were seen as black dots within the nuclei of the cells. The mean number of AgNOR per nu- cleus was calculated, and for each animal, a total of 1200 cells were randomly assessed in the control and experimental groups.

\section{Statistical analysis}

The statistical analysis and deviations (SD) to organs and tumor weight were performed using GraphPad Prism 5.0 for windows (GraphPad Software San Diego, CA, USA) and the data were expressed as replicate means $\pm S D$. Significant differences were established using one-way analysis of variance (ANOVA) and Turkey's test at $p<0.05$ were considered significant. The mean number of AgNOR per nucleus was calculated using the SPSS 15.0 program and the Students test, with the significance level set at $5 \%(p<0.05)$. The lethal concentrations $\left(\mathrm{LC}_{50}\right)$ was calculated using probit analysis with a reliability interval of 90\% using the StatPlus 1682006 software (AnalystSoft, Canada).

\section{Results}

Cytotoxicity tests on the carcinogenic cell lines submitted to the ether extract at concentrations of 6.5, 12,25 and $50 \mu \mathrm{g} \mathrm{mL}^{-1}$ achieved the following respective inhibition percentages: 60, 70, 72 and 78\% for HEp-2; 36, 42, 61 and 63\% for $\mathrm{NCl}-\mathrm{H} 292$; and $47,52,80$ and $80 \%$ for KB cells (Figure 1A). The BAR achieved lower inhibition percentages, suggesting synergism between the substances in the organic extract: 49, 54, 61 and 66\% for HEp-2; 36,7, $42,61.1$ and $63.4 \%$ for $\mathrm{NCl}-\mathrm{H} 292$; and $43,53,71$ and $77 \%$ for $\mathrm{KB}$ cells at concentrations of $2.5,5.0$, 10 and $20 \mu \mathrm{g} \mathrm{mL}^{-1}$, respectively (Figure 1B).

The $50 \%$ inhibitory concentration (IC50) of the purified substance and the ether extract is shown on table 1. The BAR was active against all the tested neoplastic cells. The most sensitive was the HE-p2 cells. The solid tumors reached $1.42 \mathrm{~g}$ in the experimental group and $2.65 \mathrm{~g}$ in the $\mathrm{C}^{-}$group (Figure 1 A). A reduction in weight $(* * p<0.05, F=225.7)$ was found in the kidneys $(0.39 \mathrm{~g})$ and liver $(2.11 \mathrm{~g})$, whe- 
Figure 1: Adenocarcinoma of Larynx (HEp -2), Squamous Cell Lung Carcinoma (NCl-H292) and Nasopharyngeal Squamous Cell (KB) treated in vitro (\% inhibition) with compounds from Cladia aggregata. A: ether extract; B: purified BAR.

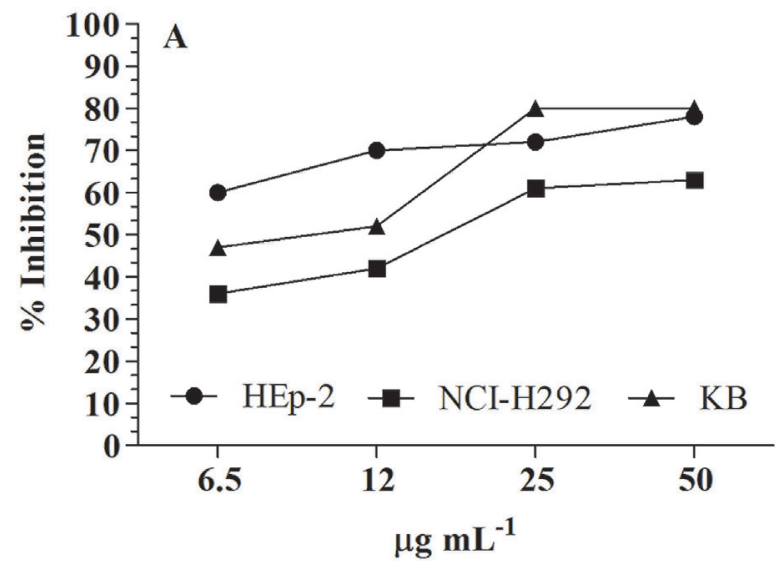

reas a slight increase was found in the spleen $(0.21$ g) (Figure 2 B) (DL50= $\left.765 \mathrm{mg} \mathrm{kg}^{-1}\right)$. When compared to the negative control, the reduction of organs weight was not significant, negative control vs liver (mean diff. $0.02368,95 \% \mathrm{Cl}$ of diff. -0.2485 to $\left.0.2959,{ }^{*} p<0.05\right)$, negative control vs kidney (men diff. $0.04136,95 \% \mathrm{Cl}$ of diff. -0.2309 to 0.3136 , $* * p<0.05)$ and negative control vs spleen (mean diff. $0.1887,95 \% \mathrm{Cl}$ of diff. -0.08352 to 0.4609 , $p>0.05)$. Despite of this, no histopathological changes were observed in these organs. BAR displayed

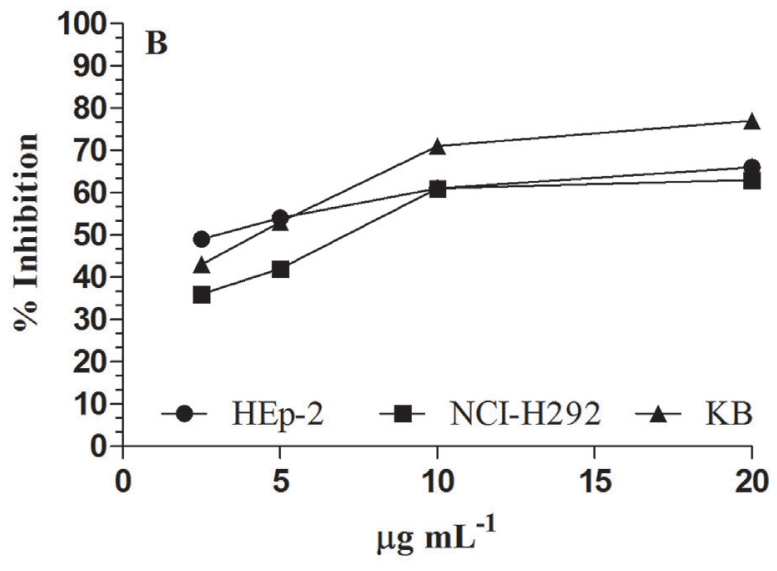

Table 1. $I C_{50}$ of ether extract and purified barbatic acid from Cladia aggregata, expressed as $\mu \mathrm{g} \mathrm{mL} \mathrm{L}^{-1}$.

\begin{tabular}{|l|c|c|}
\multicolumn{3}{|c|}{ IC50 $(\boldsymbol{\mu g ~ m L - 1})$} \\
\hline \multicolumn{1}{|c|}{ Cells line } & Ether extract & Purified BAR \\
\hline HEp-2 & ud. & 6.25 \\
\hline $\mathrm{NCl}-292$ & 19.5 & 19.6 \\
\hline KB & 8.9 & 12 \\
\hline & & ud: Undeterminated
\end{tabular}

Figure 2: A: Mean weigh of Sarcoma-180 (g); B: mean weigh of organs (g) after treatment with purified BAR (7.60 $\mathrm{mg} \mathrm{kg}^{-1}$ ) from Cladia aggregata.
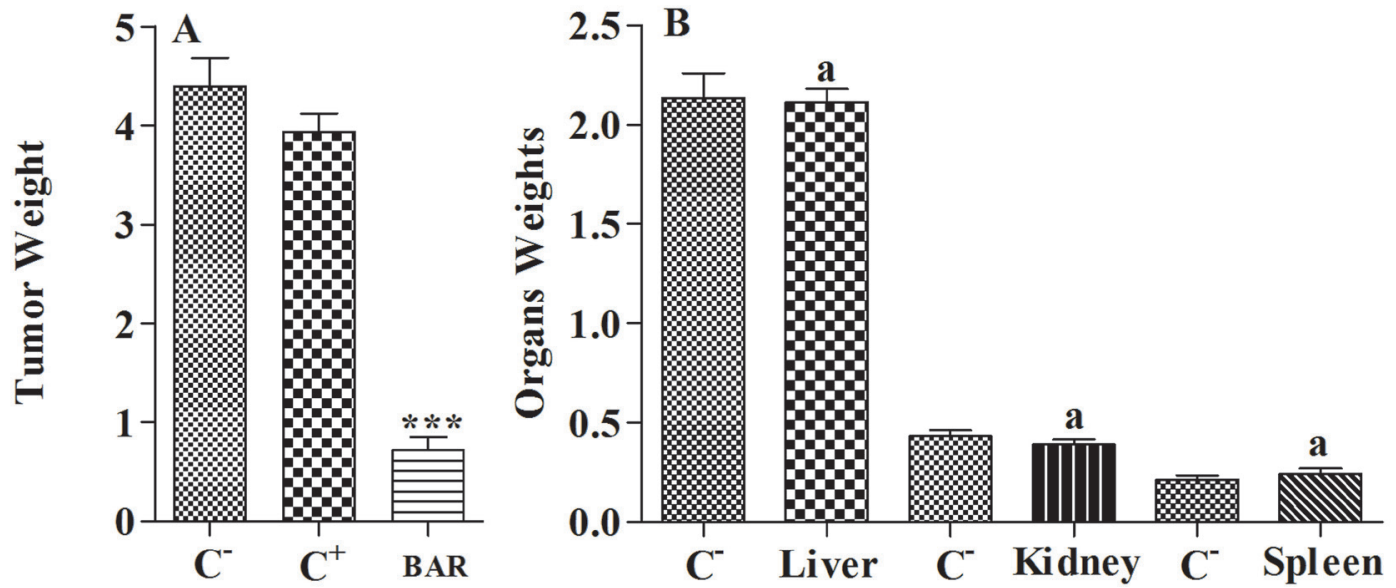

$* * *: p<0.001 . C^{+}, C:$ positive and negative controls, respectively. Letter "a" to indicate that the bars are no significantly different from each other (Tukey's test ${ }^{* *}: p<0.05$ ) when compared control group (C). 
Figure 3: Photomicrographs showing Sarcoma-180 tumor cells; AgNOR expression in $(A)$ and $(B)$, silver staining sheets of cells with marked nuclear atypical and irregular nuclear contours (C); Hematoxilin; magnification $400 \mathrm{X}$.

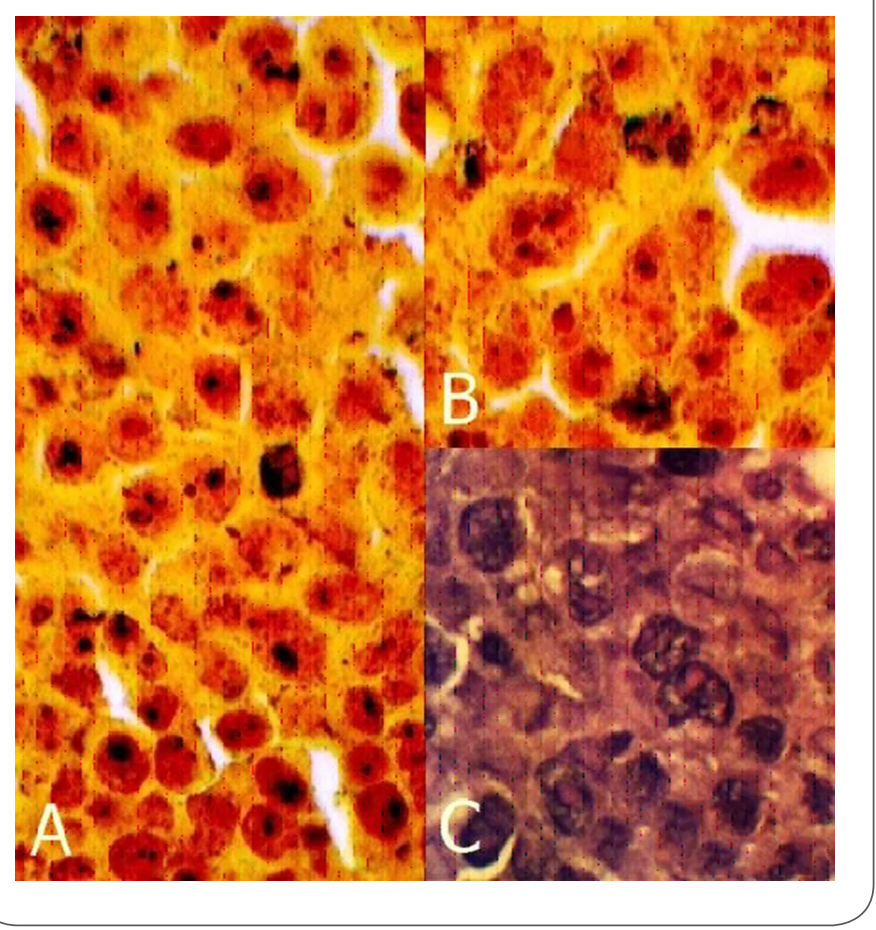

an inhibitory effect on tumor growth against Sarcoma-180, with a statistically significant $(p<0.001$, $\mathrm{F}=89.10)$ reduction in tumor weight $(61 \%)$. This final inhibition percentage was calculated using the mean of the tumors measured seven days after the administration of the BAR.

The histopathological tumor analysis revealed groups of large, pleomorphic, anaplastic cells with an increased nucleus-cytoplasm ratio. The nuclei of these cells were notably hyperchromatic, with loose chromatin and evident nucleoli. A high mitotic index with atypical mitoses was also recorded (Figure 3 A, B, C). Neoplastic invasion of muscle and adipose tissue, hemorrhagic foci and coagulation necrosis were easily recognizable.

AgNORs were easily distinguished as black spots on the nucleus of tumor cells and were visible either as large round argyrophilic structures or as small scattered units. The mean number of AgNORs per tumor cell was slightly higher in the control group $(1.55 \pm 0.35)$ than in the group treated with barbatic acid $(1.52 \pm 0.24)$, although the difference between the groups was not statistically significant ( $p$ $=0.612$ ).

\section{Discussion}

Recently, the screening of lichen substances against malignant mesothelioma MM98, vulvar carcinoma A431 and $\mathrm{HaCat}$ keratinocytes revealed sensitivity to usnic, salazinic, vulpinic and gyrophoric acids. The most pronounced cytotoxic activity was attributed to usnic acid. A combination of gyrophoric and usnic acids is reported to promote an increase in tissue regeneration [20]. Usnic acid is considered a potent inhibitor of DNA synthesis in breast cancer cells, with an $\mathrm{IC}_{50}$ of 4.2 and $5.0 \mu \mathrm{g} \mathrm{mL}^{-1}$ when extracted from C. arbuscula and Alectoria ochroleuca, respectively [21]. BAR from C. aggregata showed cytotoxic activity against HEp-2 cells in low concentration $\left(\mathrm{IC}_{50} 6.25\left(\mu \mathrm{g} \mathrm{mL} \mathrm{L}^{-1}\right)\right.$, a superior result when compared to methanol extract from Cetraria islandica and Vulpicida canadensis that possess fumarprotocetraric, protocetaric, vulpinic and usnic acids $\left(148 \mu \mathrm{g} \mathrm{mL}^{-1}\right)$ [22].

Other species of Cladoniaceae (Cladonia substellata, C. crispatula and C. dendroides), which occurs over sandy soils in tableland relieve, savannah like vegetation in the state of Paraíba (Brazil) have also been tested against adenocarcinomas. The most efficient were extracts from C. substellata due to the presence of usnic and stictic acids. The organic extracts of C. substellata at $50 \mu \mathrm{g} \mathrm{mL}$ achieved over $80 \%$ inhibition of prostatic (PC3) and mammary adenocarcinomas (MDA - MB 231) as well as over 90\% inhibition of leukemia (P388 and L1210) [10]. The authors also analyzed the activity of lichens collected in Alhandra and Santa Rita (Paraíba, Brazil) and reported that extracts from C. substellata and C. verticillaris achieved $80 \%$ inhi- 
bition of Sarcoma-180 as well as $73 \%$ and $64 \%$ inhibition for Ehrlich carcinoma, respectively. This activity has been attributed to the usnic, fumarprotocetraric acids and atranorin found in these species [10]. Santos et al. [11] also studied Sarcoma-180 and found that nanoencapsulated usnic acid reduced the tumor and considerably reduced its toxic action at the level of hepatocytes in comparison to the free form of this compound.

Different fractions, isolated from the lichen Usnea fasciata revealed that usnic acid is the main product from secondary metabolites, whereas the polysaccharides isolichenin and raffinose are the most abundant water-soluble carbohydrates. Fractions containing usnic acid, as well as those containing isolichenin, showed moderate activity against Sarcoma-180 and Ehrlich tumor cells. High antitumor activity, near $90 \%$ inhibition, was found associated with the fraction containing raffinose [23]. Usnea esculenta and U. longissima extracts, which contain usnic acid, have also been found to inhibit the growth of human melanoma at 31.2\% and $34.9 \%$, respectively, whereas the control group with ascorbic acid grew by $54.0 \%$ [7]. These previous studies with Cladoniaceae corroborate our results. They demonstrate the anticancer potential of lichens substances obtained from Cladoniaceae. Other metabolites, such as sphaerophorin and pannarin, are reported to be active against tumors (melanomas) by inducing apoptosis [13].

Nucleolar organizer regions (NORs) are chromosome regions containing rRNA (ribosomal RNA) genes. NORs also contain a set of acidic, non-histone proteins that bind silver ions and are selectively visualized by silver methods in histopathological samples. These proteins stained by silver are called AgNORs, whose quantity increases in parallel with ribosome biogenesis [24, 25]. The AgNORs proteins quantity represents a valuable parameter of cell proliferation, ploidy or protein synthesis [26]. Besides, these proteins play a fundamental role in the control of ribosomal
RNA transcription and are defined as markers of "active" ribosomal genes. The close relationship between the rate of cell proliferation and ribosomal biogenesis is well established [27]. In our study, the administration of barbatic acid did not influence significantly the expression in vivo of AgNOR proteins in Sarcoma-180 cells. However, the treatment occasioned a significant reduction in tumor weight. This fact suggests that other effects than reducing cellular proliferation or ribosomal synthesis appear to be of overriding importance in this tumor type control.

BAĈKOROVÁ et al. [28] observed that atranorin induced a massive loss in the mitochondrial membrane potential along with caspase 3 activation and phosphatidylserine externalization. In base of the obtained data the authors proposed that the mechanism of action this secondary metabolite was the activation of the programmed cell death through the mitochondrial pathway. Since the barbatic acid is a depside, like atranorin, is quite possible to have the same mechanism of action. Therefore, a possible explanation for the significant in vitro and in vivo antineoplastic effect provided by barbatic acid may be related to apoptosis triggering.

\section{Conclusion}

Both BAR and ether extract from C. aggregata showed inhibitory action against tumours and cancer cells, as well as low toxicity, and results were ratified by histopathological and mitotic analysis.

The remarkable in vitro action against tumour cells is also suggested by synergic effect between substances present in the ether extract.

These findings strongly suggest that the barbatic acid is a promising antitumor agent, being this study was first described regarding this kind of biological activity, opening new perspectives to develop new drugs with antitumor activity. 


\section{Author's contributions}

MCBM contributed to experimental design, isolation and purification of barbatic acid, statistical analyses and writing the text.

TAR, TGS and TDSS contributed to bioassays with cells and tumours.

MPCN contributed to isolate and purification barbatic acid.

TGS is Associate Professor of Antibiotic Department, Universidade Federal de Pernanbuco, is specialist in pharmacology and toxicology of natural products.

NPS contributed to histopathological analysis.

FCAAJ contributed to histopathological analysis (Agnor).

EPSF collaborated in the planning of experimental design, chemical analysis of results, writing and revising the text.

ECP collaborated in the planning of experimental design, analysis of results, writing and revising the text.

NHS analysis of results, writing and revising the text.

All authors read and approved the final version of the manuscript.

\section{Authors' information}

MCBM is post-doctoral researcher of Geographical Sciences and Biochemistry Departments of Universidade Federal de Pernambuco-UFPE, Brazil and specialist in lichen biotechnology.

TAR and TDSS are PhD students, respectively of Biological Sciences and Pharmaceutical Sciences Programs, both of Universidade Federal de Pernambuco-UFPE, Brazil

MPCN is PhD student of Biochemistry, Faculdade de Medicina de Ribeirão Preto, São Paulo, Brasil.

NPS, FCAAJ and EPSF are Associate Professors of Vitória Academic Centre, at Vitória de Santo Antão, Universidade Federal de Pernambuco-UFPE, Brazil. They are, respectively, expert in neoplastic research, histology and pathology, and experimental biochemistry.

ECP is full professor of Geographical Sciences Department, Universidade Federal de Pernambuco, specialist in biotechnology and applied lichenology

NHS is full professor of Biochemistry Department, Universidade Federal de Pernambuco, specialist in lichen chemistry and natural products.

\section{Acknowledgements}

MCBM thanks to her post-doctoral grant to CAPES and FACEPE (National and State fostering agencies). ECP thanks to CNPq for individual grant in research productivity.

\section{Competing interests}

The authors declare no competing interests.

\section{References}

1. Bačkorová M, Bačkor M, Mikeš J, Jendželovský R, Fedoročko P. Variable responses of different human cancer cells to the lichen compounds parietin, atranorin, usnic acid and gyrophoric acid. Toxicol in Vitro 2011, 25: 37-44.

2. Hawksworth DL, Honegger R. The lichen thallus: a symbiotic phenotype of nutritionally specialized fungi and its response to gal produces. Claredon Press. pp. 77-98. 1994.

3. Shrestha G, El-Naggar AM, St Clair LL, O'Neill K. Anticancer Activities of Selected Species of North American Lichen Extracts. Phytother. Res 2015, 29: 100-107.

4. Morita H, Tsuchiya $T$, Kishibe $K$, Noya S, Shiro M, Hirasawa Y. 2009. Antimitotic activity of labaric acid and a new benzofuran, sakisacaulon a from Stereocaulon sasakii. Bioorg Med Chem Lett 2009, 19: 3679-3681.

5. Kosanić M, Ranković B, Stanojković T, Rancić A, Manojlović N. Cladonia lichens and their major metabolites as possible natural antioxidant, antimicrobial and anticancer agentes. LWT - Food Sci Technol 2014, 59: 518-525.

6. Martins MCB, Lima MJG, Silva FP, Azevedo-Ximenes E, Silva NH, Pereira EC. Cladia aggregata (lichen) from Brazilian Northeast: chemical characterization and antimicrobial activity. Braz Arch Biol Technol 2010, 53: 115-122. 
7. Nóbrega NA, Ribeiro SM, Pereira EC, Marcelli M, Martins MCB, Falcão EPS, Gusmão NB, Silva NH. 2012. Produção de compostos fenólicos a partir de células imobilizadas do líquen Parmotrema andinum (Müll. Arg.) Hale e avaliação de atividade antimicrobiana. Acta Bot Bras 2012, 26: 101-107.

8. Ari F, Celikler S, Oran S, Balikci N, Ozturk S, Ozel MZ, Ozyurt D, Ulukaya E. Genotoxic, cytotoxic, and apoptptic effects of Hypogymnia physodes (L.) Nyl. on breast cancer cells. Environ Toxicol 2012. DOI 10.1002/tox.

9. Kosanić M, Ranković B, Stanojković T. Investigation of selected serbian lichens antioxidant, antimicrobial and anticancer properties. J Anim Plant Sci 2013, 23: 1628-1633.

10. Lima RMC, Nascimento SC, Pereira EC, Campos-Takaki GM. Atividade citotóxica e antitumoral de extratos liquênicos. Bol Soc Brot., 1990, v. 63, p. 339-348.

11. Santos NPS, Nascimento SC, Wanderley MSO, Pontes-Filho NT, Castro CMMB, Pereira EC, Silva NH, Honda NK, Magalhães NSS. Nanoencapsulation of Usnic Acid: An Attempt to Improve Antitumour Activity end Reduce Hepatotoxicity. Eur J Pharm Biopharm 2006, 64: 154-160

12. Moo- Sung K, Hong-Bum C. Melanogenesis inhibitory effects of methanolic extracts of Umbilicaria esculenta and Usnea longissima. J Microbiol 2007, 45: 578-582.

13. Russo A, Piovano M, Lombardo L, Garbarino J, Cardile V. Lichen metabolites prevent UV light and nitric oxide-mediated plasmid DNA damage and induce apoptosis in human melanoma cells. Life Sci 2008, 83: 468-474

14. O’Neill MA, Mayer M, Murray KE, Rolim-Santos HML, SantosMagalhães NS, Thompson AM, Appleyard VCL. Does usnic acid affect microtubules in human cancer cells? Brazilian Journal Biol 2010, 70: 659-664

15. Carvalho TUM, Attias M, Cunha e Silva NL, Carvalho TU. Métodos de estudo da célula. Cultura de células animais. Editoração eletrônica-Fenorte/VENT, Rio de Janeiro, Brasil. 1996.

16. Geran RH, Greenberg GNH. 1990. Protocol for screening of agent and natural products against animal tumors and other biological system. Cancer Chemoth Rep 1990, 3: 1-103.

17. Karber G, Behrens B. Statistical methods in biological assay. Ed. Griffin Ch. and C. London. England. 1964.

18. Berlion M. Mise au point d'un system de selection de substances antitumorales: application a l'etude d'analogues struturaux de la geopetaline (Doctor's thesis). Grenoble: Universite Joseph Berlion; 1988
19. Ploton $D$, Menager $M$, Jeannesson $P$, Himber $G$, Pigeon $F$, Adnett JJ. Improvement in the staining and in the visualization of the argyrophilic proteins of the nucleolar organizer region at the optical level. Histoche J 1986 I18: 5-14.

20. Burlando B, Ranzato E, Volente A, Appendino G, Pollastro F, Verotta L. Antiproliferative effects on tumour cells and promotion of keratinocyte wound healing by different lichen compounds. Planta Med 2009, 75: 607-613.

21. Einarsdóttir E, Groeneweg J, Björnsdóttir GG, Harðardottir G, Omarsdóttir S, Ingólfsdóttir K, Ögmundsdóttit HM. Cellular mechanisms of the anticancer effects of the lichen compound usnic acid. Planta Med 2010, 76: 969-974.
Publish in International Archives of Medicine

International Archives of Medicine is an open access journal publishing articles encompassing all aspects of medical science and clinical practice. IAM is considered a megajournal with independent sections on all areas of medicine. IAM is a really international journal with authors and board members from all around the world. The journal is widely indexed and classified Q1 in category Medicine. 